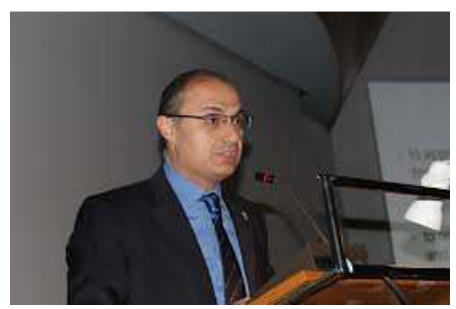

\title{
A Pioneer of Italian Sports Pedagogy and Philosophy
}

Authors' contribution:

A) conception and design of the study

B) acquisition of data

C) analysis and interpretation of data

D) manuscript preparation

E) obtaining funding
Emanuele Isidori ${ }^{1}$, Jerzy Kosiewicz ${ }^{2}$

${ }^{1}$ University of Roma "Foro Italico", Italy

${ }^{2}$ Josef Pilsudski University of Physical Education in Warsaw, Poland

KEYWORDS

The biography we present here in this issue of our journal refers to the story of Italian scholar, educationist, and philosopher, Emanuele Isidori, Vice-Rector for International Relations and Cooperation and head of the Laboratory of General and Sport Pedagogy of the Foro Italico University of Rome in Italy. The biography of Emanuele tells us the story of a pioneer both in sports pedagogy and sports philosophy in his home country of Italy, where the idealist tradition and some prejudices regarding sport and its science seem to have hindered the development process of the two subjects for many years. What emerges from this story is the commitment and strenuous effort of the scholar to develop sports humanities in his country and to help his university and other Italian researchers interested in the scholarly field develop their knowledge through collaboration with the most prestigious European institutions devoted to the study of sport and physical activity. pedagogy, philosophy, sport, Italy

\section{Short biography of a scholar of sports humanities}

Emanuele Isidori was born on March 28th, 1971 in Viterbo, a lovely medieval city in the northern part of the Lazio region between the beautiful hills of Tuscany and Umbria. He received a Catholic education and attended the local Liceo Classico (a high school devoted to the study of classical languages and heritage) dedicated to the memory of the partisan and teacher Mariano Buratti, who was tortured and killed by fascists in 1944. He graduated from the high school in 1989 and went to Rome to attend the Faculty of Humanities of the Sapienza University of Rome, where he earned a master's degree in Classical Philology in 1994. In the same year, he enrolled at the University of Siena, one of the most beautiful Italian cities, and began to attend courses in philosophy and pedagogy at the Department of Philosophy and Social Sciences. He earned his second master's degree in philosophy defending a thesis in general pedagogy (on the topic of educational hermeneutics) in 1997. After that, he went back to Rome and enrolled at the Rome Tre University, Faculty of Education, where he attended a one-year master's degree in adult education (1998). At the end of this course, he moved to Perugia, another beautiful medieval town famous for its ancient university, and began to attend a $\mathrm{Ph} . \mathrm{D}$. course in educational sciences focusing on issues related to teachers' education. In 2003, he earned his $\mathrm{Ph} . \mathrm{D}$. in educational sciences defending a thesis on the induction year of teachers in Italy and abroad. 
In 1997, Emanuele started to work as an assistant professor at the Italian Institute of Physical Education of Rome (ISEF), the only public institute of this kind in Italy. In 1998, the institution of higher education was transformed into the University Insitute of Motor Sciences of Rome. In 2008, the University Institute became the Foro Italico University of Rome. The story of Emanuele as a scholar in the sports humanities is strictly tied to that of this beloved institution. The beautiful complex of Foro Italico is a special place for Emanuele. The place has always inspired him and continues to inspire and motivate his commitment to the promotion of sport values through educational and philosophical research. The university is the fourth public university in Rome, and it is the heir of the Italian Academy for Physical Education founded in 1928. Its urban campus is located in the northern part of Rome in the historical area of Foro Italico, a venue of 10,000 square meters that hosted the Olympic Stadium and prestigious annual tournaments and competitions.

In 2006, Emanuele became an associate professor of general and social pedagogy and head of the Laboratory of General Pedagogy. In 2014, he was appointed Vice-Rector for International Relations and Cooperation of the Foro Italico University of Rome. Moreover, Emanuele earned other master's degrees: in E-Learning (2012) from the University of Tuscia (the university of his home town, Viterbo); in the Didactics of Italian Language and Culture to Foreigners (2015) from the University of Rome Tor Vergata; and in International Relations (2016) from Niccolò Cusano University in Rome, defending a thesis in sports diplomacy. In 2013, he also earned his second Ph.D. (summa cum laude) in physical activity and health, this time from the University of Alfonso X in Madrid, Spain. The thesis that he defended in Madrid, which was written in Spanish, focused on the sports coach as an educator and his/her philosophical and pedagogical paradigms.

Emanuele is very proud of his university, and he is totally engaged in the promotion of its image and values in Italy and abroad. He has identified the growth of his professional career with that of his institution. He was the first Italian university professor to teach sport pedagogy and sport philosophy in an Italian university.

\section{Appointments}

Member of the following doctoral schools:

- University Babes-Bolyai of Cluj (Romania), program in Physical Activity and Sport

- Universidad Catolica San Antonio de Murcia (Spain), program in Physical Activity and Sport

- Foro Italico University of Rome (Italy), program in Sport Sciences

\section{Other Appointments}

Editor-in-chief of the following journals:

- Rivista Internazionale di Diritto ed Etica dello sport, ISSN: 2408-4166

- Journal of Social Philosophy Research, ISSN: 2372-4579

- Italian Journal of Sports Pedagogy (founder and manager), www.ripes.eu, ISSN: 2499-541X

\section{Editorial Board member of the following journals}

- Educazione Nuova, Laboratorio Montessori, ISSN: 1974-8787

- Tándem, Didáctica de la educación física, ISSN: 2014-4768

- Physical Culture and Sport. Studies and Research, ISSN: 2081-2221

- Educatio Artis Gymnasticae Studia Universitatis Babes-Bolyai, ISSN (print): 1453-4223

- Fair Play, Revista de Filosofía, Ética y Derecho del Deporte, ISSN: 1224-1652

- Contextos Educativos: Revista de Educación, ISSN: 1575-023X

- Telethusa, Revista del Centro de Investigación Flamenco, ISSN: 1989-1628

- Cultura, Ciencia y deporte, ISSN: 1696-5043

- Journal of Sport Sciences Researches, ISSN: 2548-0723 


\section{Editor-in-chief of the following scholarly books series}

- Education and Sport Studies, scholarly book series; Publishing: Nuova Cultura, Rome.

- Teoria e storia dell'educazione, scholarly book series; Publishing: Sette Città, Viterbo.

- Scienze dello sport, scholarly book series; Publishing: Sette Città, Viterbo.

- Quapeg, scholarly book series; Publishing: Foro Italico University of Rome, Rome.

\section{Member of the Scientific Board of the following scholarly books series}

- Pedagogia del Corpo e del Movimento; Publishing: Franco Angeli Publisher, Milan.

- Strumenti del CreSF “G. A. Colozza,” University of Molise, Italy; Publishing: Pensa Multimedia, Lecce.

- Collana Laboratorio Montessori; Publishing: Aracne Editrice, Rome.

\section{Coordinator and member of the following international research groups:}

- Italo-German Sport Pedagogy and Philosophy Research Unit, http://sportpedlab.wordpress.com/ (Coordinator; since 2011)

- International Research Group on Education, Body, and Values (Italy, Latvia, Romania; Coordinator; since 2010)

- International Research Group on Physical Education Teachers' Philosophical Profiles (Italy, Romania, Turkey; Coordinator; since 2011)

- AFYDO: Research Group on Leisure Education, University of La Rioja, Spain (Member; since 2010)

- Areté (UCAM), http://investigacion.ucam.edu/educacion-fisico-deportiva/equipo/ (Member; since 2010

\section{Main Awards}

- 2014: AEDC (Asociación Española de Deportes Colectivos), Sport Pedagogy Award

- 2015: Region of Murcia, Spain, Prize for the Research, Science, and Innovation in Sport for the Research on the Dual Career of Student Athletes - ESTPORT Erasmus+ Project

- 2016: Journal Ciencia, Cultura y Deporte, Best Paper of the Year (title of the paper: "Sport and Democracy: Philosophical Trends and Educational Challenges in Contemporary Society")

\section{Official Visiting Professorships}

- California State University, Long Beach, USA, Department of Kinesiology, July-September 2013

- California State University, Long Beach, USA, Department of Kinesiology, August-September 2014

- University of Valladolid, Spain, January-March 2016

\section{International Scholarships}

DAAD - Deutscher Akademischer Austauschdienst, Leipzig University, July-September 2011

\section{Appointments as an invited speaker and lecturer}

He has been invited as a speaker and lecturer at several conferences and universities in Europe (Spain, Turkey, Italy, Latvia, Poland, Romania, Germany, etc.), including the following:

- International Olympic Academy (IOA; lecturer), Ancient Olympia, Greece, May 2014; http://www.ioa.org.gr/

- Zentrum für interdisziplinäre Forschung (ZIF): Center for Interdisciplinary Research (lecturer), Bielefeld, Germany, September 2011; http://www.uni-bielefeld.de/ZIF/

- Latvian Presidency of the EU, 2015 


\section{Appointments as member of the following scientific societies}

- SIPED (Società Italiana di Pedagogia)

- IAPS (International Association for the Philosophy of Sport)

- ISSS (International Society for the Social Sciences of Sport)

- SFI (Società Filosofica Italiana)

- ALFID (Asociacion Latina de Filosofia del deporte)

- CPSA (Czech Philosophy of Sport Association)

- PASSPE (Pan Asian Society of Sports and Physical Education)

- SIRD (Italian Society for the Research in Didactics)

- RVP (Council for Research in Values and Philosophy)

\section{Main courses taught}

- Methodology of Educational Research

- General Pedagogy

- Sport Philosophy

- Social Pedagogy

- Sport Pedagogy

- History of Sport and Physical Education

- Sport Geography

- Tourism Education

- Lifelong Learning and Human Resources Management

He has taught as a visiting professor (Erasmus Program) at the following universities: University of Las Palmas de Gran Canaria; University of Leipzig (Germany); University of León (Spain); University BabesBolyai of Cluj-Napoca (Romania); University of Physical Education of Warsaw (Poland); Latvian Academy of Physical Education, Riga (Latvia); University of Valladolid (Spain); University of Valencia (Spain); University of Porto (Portugal); University of Athens (Greece); University of Prague (Czech Republic); University of Coimbra (Portugal); University of Malta (Republic of Malta); University of Granada (Spain); University of Murcia (Spain); University of Salamanca "Pontificia" (Spain); University of Bordeaux II (France); University of Castellon (Spain); Polytechnic University of Madrid (Spain); California State University, Long Beach; Complutense University of Madrid.

\section{Research Grants}

Since 2002, he has been awarded several research grants from various funding bodies in Italy and abroad. Among them, we want to stress the following from 2014-2017: Erasmus+ Developing an Innovative European Sport Tutorship Model for the Dual Career of Athletes (557204-EPP-1-2014-ES-SPO-SCP) in partnership with UCAM, Malta University, Thessaly University, and Leeds Trinity University.

\section{Main research fields and interests}

$\mathrm{He}$ is the author and co-author of more than 160 publications (14 books, 8 edited books, 70 articles, 54 book chapters, 22 papers in proceedings) written in three main languages: Italian, English, and Spanish. His primary research interests are as follows: methodology of educational research and sport values; epistemology of sport, body, and education; training of physical education teachers and sports coaches; sport pedagogy and e-learning; sport ethics; epistemology of sport pedagogy; education, sport, and cultural studies; tourism and leisure education; family and sport education; the referee as educator; the sports coach as educator. Below is an up-to-date list of his main publications. 


\section{Main Publications}

Books

- Isidori, E. (2017). Pedagogia e sport. La dimensione epistemologica ed etico-sociale [Pedagogy and sport: The epistemological and socio-ethical dimension], pp. 1-178. Milano: Franco Angeli. ISBN: 9788891751737

- Isidori, E. (2016). Pedagogia, sport e relazioni internazionali. Dall'analisi del contesto allo sviluppo della metodologia [Pedagogy, sport, and international relations: From the analysis of context to methodology]. Roma: QUAPEG. ISBN: 9788822826459, DOI: 10.5281/zenodo.59154

- Isidori, E. (2013). El entrenador como educador: perspectivas filosóficas y pedagógicas [The sports coach as educator: Philosophical and pedagogical perspectives], pp. 1-308. Viterbo: Sette Città. ISBN: 978-88-7853-337-0

- Isidori, E. (2012). Filosofia dell'educazione sportiva. Dalla teoria alla prassi [Philosophy of sport education: From theory to practice], pp. 1-123. Roma: Edizioni Nuova Cultura. ISBN: 9788861347380 , DOI: $10.4458 / 7380$

- Isidori, E. (2009). La pedagogia dello sport [Sports pedagogy], pp. 2-110. Roma: Carocci Editore. ISBN: 8843049151

- Isidori, E. (2009). Outline of Sport Pedagogy: Introduction and Research Essays. Roma: Aracne. ISBN: 9788854826861

- Isidori, E. (2006). Valori, sport e agenti educativi. La prospettiva psico-pedagogica [Values, sport, and educational agents: The psycho-pedagogical perspective], pp. 3-78. Roma: QUAPEG. ISBN: 9786050360813

- Isidori, E. (2005). Ermeneutica e pedagogia della persona. Dal dialogo alla cura [Hermeneutics and pedagogy of the person: From the dialogue to the taking care], pp. 2-141. Roma: Aracne. ISBN: 88-5480159-3

- Isidori, E. (2005). Il modello decostruzionista nella ricerca pedagogica [The deconstructionist model and its application to educational research], pp. 2-104. Roma: Aracne. ISBN: 88-548-0136-4

- Isidori, E. (2004). La pedagogia del classico. Origine di un modello da Orazio alla modernità [Theory and practice of classical education: From Horace to modernity], pp. 1-108. Roma: QUAPEG. ISBN: 9788826025667, DOI: https://zenodo.org/record/293086

- Isidori, E. (2003). La formazione degli insegnanti principianti. Problemi e strategie [Teachers' education: Issues and strategies], pp. 8-210. Perugia: Morlacchi. ISBN: 88-88778-57-8

- Isidori, E. (2002). La pedagogia come scienza del corpo [Pedagogy as a science of the body], pp. 3-108. Roma: Anicia. ISBN: 88-7346-031-3

Books in collaboration

- Isidori, E. \& Fraile, A. (2008). Educazione, sport e valori. Un approccio pedagogico critico-riflessivo [Education, sports, and values: A pedagogical and critical-reflective approach], pp. 1-98. Roma: Aracne. ISBN: 9788854817029

- Isidori, E., Di Pietro, B., \& Pérez Trivino, J.L. (2013). Arbitraggio sportivo, etica ed educazione: prospettive di analisi filosofico-giuridica [Sports refereeing, ethics, and education: Philosophical and juridical perspectives]. Viterbo: Sette Città. ISBN: 978-88-7853-335-6

- Isidori, E. \& Reid, H.L. (2011). Filosofia dello sport [Sports philosophy], pp. 78-150. Milano: B. Mondadori. ISBN: $886159638 X$

\section{Edited books}

- Isidori, E. (Ed.) (2002). Octavi Fullat. Le parole del corpo [Words of the body]. Di FULLAT OCTAVI. Roma: Anicia. ISBN: 88-7346-030-5

- Isidori, E. \& Saenz de Jubera, M. (Eds.) (2016). Leisure and Family: Educational Contexts, pp. 1-167. Roma: QUAPEG. ISBN: 9788822880574, DOI: 10.5281/zenodo.220888

- Isidori, E., Taddei, F., \& Ramos Echazarreta, R. (Eds.) (2016). Saggi di Pedagogia dello sport [Essays on sports pedagogy], pp. 1-135. Roma: QUAPEG. ISBN: 9788826037707, DOI: 10.5281/zenodo. 376808 
- Isidori, E., Madella, P., Reid, H.L., \& Fazio, A. (Eds.) (2015). Filostrato. Sull'allenamento [Philostratus: On training]. Viterbo: Sette Città. ISBN: 978-88-7853-382-0

- Isidori, E., Lopez Frias, J., \& Müller, A. (Eds.) (2014). Philosophy, Sport and Education: International Perspectives. Viterbo: Sette Città. ISBN: 978887853346-2

- Isidori, E. \& Aranda, A.F. (Eds.) (2012). Pedagogia dell'allenamento. Prospettive metodologiche [Pedagogy of sports coaching: Methodological perspectives]. Roma: Edizioni Nuova Cultura. ISBN: 9788861347373

- Isidori, E. \& Fraile Aranda, A. (Eds.) (2011). La pedagogia del deporte hoy. Escenarios y desafios [Sports pedagogy: Scenarios and challenges]. Roma: Edizioni Nuova Cultura. ISBN: 9788861346062

\section{Selected articles}

Isidori's main articles have been divided here into six specific study areas: studies concerning the general topics of sport pedagogy as a science; studies concerning the social topics of sport pedagogy as a science; studies relating to sport philosophy and sport ethics; studies related to the methodology of educational research applied to sport; studies related to the training of teachers of physical education; and studies tied to the dual career of student athletes.

Studies in general sport pedagogy.

In this area, the contributions of Isidori as a first, second, or third author (but always responsible for the research) has focused on the foundation of sport pedagogy as a science and the examination and study of all main issues dealing with sport education using an interdisciplinary scholarly approach. His main publications in this area are as follows:

- Isidori, E. (2016). Lo sport come pedagogia agonale: presupposti teorici e metodologici [Sport as agonal pedagogy: Theoretical and methodological foundations]. In A. Cunti (Ed.), Sfide dei corpi. Identità Corporeità Educazione [Challenges of the body: Identity, body reality, and education]. Milano: Franco Angeli, pp. 195-211. ISBN: 9788891743794

- Isidori, E. (2016). Synesis, phronesis and metis: A hermeneutical contribution to sport pedagogy as a human science. In A. Gál, J. Kosiewicz, \& T. Sterbenz (Eds.), Sport and Social Sciences with Reflection on Practice (pp. 180-192). Warsaw: Josef Piłsudski University of Physical Education and ISSS. ISBN: 978-83-936610-7-7

- Chiva Bartoll, O., Salvador García, C., \& Isidori, E (2016). La pedagogía del deporte desde una interpretación filosófico-hermenéutica agonal [Sports pedagogy from an agonal hermeneutical interpretation]. OPCIÓN, 81, 213-237. ISSN: 1012-1587

- Isidori, E. (2015). La comunicazione spettacolarizzata: una riflessione pedagogica tra Debord e YouTube [Spectacular communication: A pedagogical reflection between Debord and YouTube]. METIS, 2, 1-13. ISSN: 2240-9580

- Isidori, E. (2015). Pedagogia dello sport [Sports pedagogy]. In A. Cunti (Ed.), Corpi in formazione. Voci pedagogiche [Bodies and education: Pedagogical entries]. Milano: Franco Angeli, pp. 184-191. ISBN: 9788891728739

- Isidori, E. (2015). Orientamento e sport [Guidance and sport]. In A. Cunti (Ed.), Corpi in Formazione. Voci pedagogiche [Bodies and education: Pedagogical entries]. Milano: Franco Angeli, pp. 172-177. ISBN: 9788891728739

- Isidori, E. (2015). Sport pedagogy and well-being: A phenomenological approach. International Journal of Social Science and Humanities Research, 3(4), 1-6. ISSN (print): 2348-3156, ISSN (online): 23483164

- López Frías, F.J., Isidori, E., \& Hadjistephanou Papaellina, C. (2015). Greek mythology and education: From theory to practice. Procedia. Social and Behavioral Sciences, 197, 595-599. ISSN: 1877-0428, DOI: $10.1016 /$ j.sbspro.2015.07.199

- Isidori, E. (2015). Flamenco, cine y educación: para una pedagogia del duende [Flamenco, movies, and education: Towards a duende's pedagogy]. CCD. Ciencia, Cultura, Deporte, 29(10) Supl., 63-66. ISSN (print): 1696-5043, e-ISSN: 1989-7413

- Isidori, E. \& Fazio, A. (2015). Filostrato e l'allenamento: per una pedagogia neo-antica dello sport [Philostratus and sport training: A contribution to a neo-ancient pedagogy]. In P. Madella, H.L. Reid, E. 
Isidori, \& A. Fazio (Eds.), Filostrato. Sull'allenamento [Philostratus: On sport training] (pp. 35-50). Viterbo: Sette Città. ISBN: 978-88-7853-382-0

- Isidori, E. (2015). La pedagogia dell'alimentazione: contributo ad una teoresi educativa [The pedagogy of nutrition: Contribution to an educational theory]. Cqia Rivista, Formazione, Lavoro, Persona, 5(14), 119-134. ISSN: 2039-4039

- Isidori, E. (2015). Sport, dignity and human rights. In K. Georgiadis (Ed.), Olympic Values in Education (pp. 31-44). Athens-Ancient Olympia: IOA and IOC, SAITI Publications. ISBN: 978-960-9454-30-8

- Isidori, E. (2015). La pedagogia dell'orientamento sportivo: una prospettiva teorica [Pedagogy of sport guidance: A theoretical perspective]. Cqia Rivista, Formazione, Lavoro, Persona, 13, 1-16. ISSN: 20394039

- Isidori, E. (2014). Formación de personas adultas: deporte, valores y ciudadanía a lo largo de la vida [Adult education and sport within lifelong learning]. In M. Marti-Puig, J. Gil-Gomez, \& O. ChivaBartoll (Eds.), Aprendizaje a lo largo de la vida: Reflexión y cambio [Continuous education and life: Reflections and changes] (pp. 67-88). Alata: Colonna édition. ISBN: 978-2-36984-009-1

- Isidori, E. \& Benetton, M. (2014). La pedagogia dell'allenamento sportivo tra epistemologia e lifelong learning [Pedagogy of sports coaching between epistemology and lifelong learning]. Studium Educationis, 15(2), 81-93. ISSN (print): 1722-8395, ISSN (online): 2035-844X

- Isidori, E. (2012). Le parole del corpo: educare attraverso lo sport [Words of the body: Educating through sport]. Etica per le Professioni, 3, 91-100. ISSN: 1591-7649

- Di Pietro, B., Colitti, P., Isidori, E., \& Pigozzi, F. (2012). Sports medicine and new challenges for Olympic education: Ethical and educational aspects. Medicina dello Sport, 65, 407-422. ISSN: 00257826

- Isidori, E., Müller, A., \& Kaya, S. (2012). The referee as educator: Hermeneutical and pedagogical perspectives. Physical Culture and Sport. Studies and Research, 56 (1), pp. 5-11. ISSN: 2081-2221, DOI: 10.2478/v10141-012-0023-2

- Isidori, E. (2012). Dal Mündiger Trainer al coach critico-riflessivo. Prospettive pedagogiche per ripensare l'allenatore come educatore. In Pedagogia dell'allenamento. Prospettive metodologiche [From the Mündiger Trainer to the critical reflective coach: Pedagogical perspectives to rethink the coach as an educator] (pp. 151-186). Roma: Edizioni Nuova Cultura-Roma. ISBN: 9788861347373, DOI: 10.4458/7373-07

- Isidori, E. \& Aranda, A.F. (2012). L'allenamento come pratica pedagogica. I nodi del problema. [Sport coaching and its issues]. In E. Isidori \& A.F. Aranda (Eds.), Pedagogia dell'allenamento. Prospettive metodologiche [Pedagogy of sport training: Methodological perspectives] (pp. 7-16). Roma: Edizioni Nuova Cultura. ISBN: 9788861347373, DOI: 10.4458/7373-01

- Isidori, E. (2012). Il rapporto tra pedagogia e geografia dello sport negli sport studies: prospettive interdisciplinari [The relation between pedagogy and sports geography in sports studies: Interdisciplinary perspectives]. In Geografia e sport. Prospettive di ricerca e esperienze [Geography and sport: Research perspectives and experiences] (pp. 47-62). Viterbo: Sette Città. ISBN: 978-88-7853$314-1$

- Isidori, E. (2011). La pedagogía del deporte como ciencia.Perspectivas críticas [Sports pedagogy as a science: Critical perspectives]. In La pedagogia del deporte hoy. Horizontes y desfios [Sport pedagogy today: Horizons and challenges] (pp. 1-42). Roma: Nuova Cultura. ISBN: 9788861346062

- Isidori, E., Perrino Peña M., Vicente Pedraz M. (2011). Feminine authorship and women's education in Citius, Altius, Fortius Journal (1959-1976). Physical Culture and Sport. Studies and Research, 53, 1827. ISSN: 2081-2221, DOI: 10.2478/v10141-011-0019-3

- Isidori, E. (2010). Pedagogia dello sport e culture postmoderne: prospettive per l'inclusione sociale. In La rivincita dei corpi. Movimento e sport nell'agire educativo [Sports pedagogy and postmodern cultures: Perspectives for the social inclusion] (pp. 122-135). Milano: Franco Angeli. ISBN: 9788856834727

- Isidori, E. (2009). Introduction to sport pedagogy. In E. Isidori (Ed.), Outline of Sport Pedagogy: Introduction and Research Essays (pp. 9-47). Roma: Aracne Editrice. ISBN: 978-88-548-2686-1

- Isidori, E. \& Vossel, T. (2009). Sport pedagogy, values and critical reflective methodology. A case study. In E. Isidori (Ed.), Outline of Sport Pedagogy: Introduction and Research Essays (pp. 51-82). Roma: Aracne Editrice. ISBN: 978-88-548-2686-1

- Isidori, E. (2008). Becoming a reflective practitioner in physical activity and sport. A new challenge for sport pedagogy. Studia Universitatis Babes-Bolyai. Educatio Artis Gymnasticae, 53(2), 51-60. ISSN: $1453-4223$ 
- Isidori, E. (2007). Pedagogia e paradigmi dell'educazione fisica nella scuola contemporanea [Pedagogy and physical education paradigms in the contemporary school]. In E. Isidori (Ed.), Quaderni del Laboratorio di Pedagogia Generale, 1, 5-21. Roma: Istituto Universitario di Scienze Motorie. ISBN: 9788868857240

\section{Studies in social sport pedagogy}

In this area, the contribution of Isidori, who was always responsible for the research carried out, has focused on the main educational agents and agencies of sport (coaches, teachers, parents, referees) and the specific topics related to social issues in sport pedagogy (tourism, inclusion, environment, social capital and human resources, citizenship, peace, human rights, etc.). The publications dealing with this area are listed below.

- Isidori, E. (2016). La famiglia come agente educativo dello sport [Family as an educational agent]. In M.L. Iavarone (Ed.), Sport e attività motoria per il benessere [Sport and physical activity for well-being] (pp. 35-53). Torino: Bradipolibri. ISBN: 9788896184313

- Isidori, E., Migliorati, M., \& Maulini, C. (2016). Famiglia, sport e tempo libero: strategie per una pedagogia sociale [Family, sport, and leisure]. In M. Saez de Jubera \& E. Isidori (Eds.), Leisure and Family: Educational Contexts (pp. 10-19). Roma: QUAPEG. ISBN: 9788822880574, DOI: 10.5281/zenodo. 220888

- Isidori, E. (2016). Il ginnasio pitagorico nella prospettiva della pedagogia neoantica [The Pitagorean gymnasium in light of a neo-ancient pedagogy interpretation]. In E. Isidori, F. Taddei, \& R. Ramos Echazarreta (Eds.), Saggi di pedagogia dello sport [Essays on sports pedagogy] (pp. 98-107). Roma: QUAPEG. ISBN: 9788826037707, DOI: 10.5281/zenodo.376808

- Lenartowicz, M., Isidori, E., \& Maussier, B. (2016). Sport and tourism between modernity and postmodernity. Polish Journal of Sport and Tourism, 2, 65-69. ISSN: 1899-1998

- Isidori, E., Masala, D., \& Pratesi, C.A. (2016). Sport e ambiente [Sport and environment]. In P. Salvatore (Ed.), CRUL - Comitato Regionale di Coordinamento delle Università del Lazio, Dialoghi sulla sostenibilità [Dialogues on sustainability] (pp. 139-142). Roma: Edizioni Roma TrePress. ISBN: 9788897524717

- Angelillo, E., Colitti, L., \& Isidori, E. (2016). Sport e cittadinanza: tra democrazia e diritti [Sport and citizenship: Between democracy and rights]. In P. Salvatore (Ed.), CRUL - Comitato Regionale di Coordinamento delle Università del Lazio, Dialoghi sulla sostenibilità [Dialogues on sustainability] (pp. 235-238). Roma: Edizioni Roma TrePress. ISBN: 9788897524717

- Isidori, E. (2015). Education as synesis: A hermeneutical contribution to the pedagogical theory of educational practice. Procedia. Social and Behavioral Sciences, 197, 531-536. ISSN: 1877-0428, DOI: 10.1016/j.sbspro.2015.07.183

- Isidori, E. \& Benetton, M. (2015). Sport as education: Between dignity and human rights. Procedia. Social and Behavioral Sciences, 197, 686-693. ISSN: 1877-0428, DOI: 10.1016/j.sbspro.2015.07.060

- Isidori, E., De Santis, M.G., \& Ramos Echazarreta, R. (2014). Sport, famiglia ed educazione: uno studio pilota sulle influenze dei genitori nella scelta delle pratiche sportive degli studenti universitari di scienze motorie [Sport, family, and education: A pilot study on the influences of parents on the choices related to sport activities by Italian sport sciences students]. La Famiglia. Rivista Di Problemi Familiari, 48(258), 261-279. ISSN: 0392-2774

- Isidori, E., Ramos Echezarreta, R., \& Maulini, C. (2014). Social Network, juegos virtuales y actividad físico-deportiva juvenil: ¿una «conexión» posible? [Social networks, video games, and physical activities for the youth: Is it possible there is a connection?]. In C. Ortega Nuere \& F. Bayón (Eds.), El papel del ocio en la construcción social del joven [The role of leisure in the social identity of the youth], Vol. 51 (pp. 161-176). Documentos de estudios de ocio, Bilbao: Publicaciones de la Universidad de Deusto. ISBN: 978-84-15759-43-0 
- Isidori, E. (2014). La pedagogia del turismo ed il ruolo dell' educazione turistica nella valorizzazione del territorio [The pedagogy of tourism and the function of tourism education in stressing the importance and the improving of territories]. In R. De Iulio \& A. Ciaschi (Eds.), Modelli geografici di sviluppo di aree marginali. Teorie e esperienze a confronto [Geographical models and development of marginal areas: Compared theories and experiences] (pp. 193-215). Viterbo: Sette Città. ISBN: 978-88-7853-3035

- Isidori, E., Baffa, F., \& Maulini, C. (2009). Pedagogia del humor. Una actividad fisica adaptada [Pedagogy and humor: An adapted physical activity]. TÁNDEM, 11, 51-58. ISSN: 1577-0834

- Isidori, E. (2009). Sport pedagogy through movies. A methodology to promote values in sport education for children and youths. Studia Universitatis Babes-Bolyai. Educatio Artis Gymnasticae, 54(1), pp. 5160. ISSN: $1453-4223$

Studies in sport philosophy and ethics

In this area, the contribution of Isidori has focused on the main ethical issues dealing with sport and its practice (mainly values, virtues, and doping). The author has conducted studies in this area aimed at identifying possible connections between theory and practice in the philosophy of sport. For this reason, utilizing a hermeneutical methodology based on a continental approach to philosophy, the author has carried out studies in which sport philosophy has been coupled with a practical application.

- Isidori, E. (2017). Il doping alla luce della dike educativa: tra punizione e comprensione [Doping in light of the educational Dike: Between comprehension and punishment]. In B. Di Pietro \& P. Sandulli (Eds.), Doping e diritto. Prospettive nazionali e internazionali [Doping and law: National and international perspectives] (pp. 7-22). Roma: Edizioni Fondazione Universitaria Foro Italico. ISBN: 9788826049328, DOI: https://zenodo.org/record/546415

- Isidori, E. \& Cacchiarelli, M. (2017). The ethics of education and its function within virtual learning environments. In L. Gómez Chova, A. López Martínez, \& I. Candel Torres (Eds.), Proceedings of the 11th Annual International Technology, Education and Development Conference, INTED, 2017 (pp. 8267-8274). Valencia: International Association of Technology, Education and Development (IATED). ISBN: 9788461784912, DOI: 10.21125/inted.2017.1951

- Isidori, E. (2016). L'etica nello sport [Sports ethics]. In C. Mantovani (Ed.), Insegnare per allenare [Teaching to training in sport] (pp. 305-333). Roma: Edizioni Scuola dello Sport-CONI. ISBN: 9788897337157

- Sandor, I., Pascan, A., Rusu, G., Isidori, E., Taddei, F. \& Kaya, S. (2016). An examination of philosophical profiles in physical education. A comparison between Romania and Italy. Studia Universitatis Babes-Bolyai. Educatio Artis Gymnasticae, 61, 5-14. ISSN: 1453-4223

- Isidori, E. (2016). I valori dello sport. In M. Morandi (Ed.), Corpo, educazione fisica, sport. Questioni pedagogiche [Body, physical education, sport: Pedagogical issues] (pp. 164-181). Milano: Franco Angeli. ISBN: 9788891743572

- Isidori, E. (2015). Being as movement and body: When metaphysics and cultural anthropology meet in sport education. In J. Oborny, O. Staud, \& B. Vrtiakova (Eds.), Cultural Anthropology and Sport (pp. 68-76). Comenius University of Bratislava: Bratislava. ISBN: 978-80-223-3952-0

- López Frías, F.J. \& Isidori, E. (2015). La mitología griega como herramienta para enseñar la filosofía del olimpismo [Greek mythology as a means to teach the philosophy of Olympism]. Citius, Altius, Fortius, 8(1), 9-27. ISSN: 2340-9886

- Isidori, E. (2015). Anthropology of sport education: A bio-metaphysical interpretation of the relationship between body and movement. International Journal of Interdisciplinary Research and Innovations, 3, 5-9. ISSN: 2348-1218

- Isidori, E. (2015). Philosophy of sport education: Main issues and methodology. Physical Culture and Sport. Studies and Research, 66(1), 5-13. ISSN (online): 1899-4849, DOI: 10.1515/pcssr-2015-0003

- Isidori, E. (2015). The dual career of student athletes: A pedagogical challenge. CCD. Ciencia, Cultura, Deporte, 29(10), 99-101. ISSN (print): 1696-5043, e-ISSN: 1989-7413, DOI: http://dx.doi.org/10.12800/ccd.v10i28

- Isidori, E. (2015). L'essere come movimento: una analisi ermeneutico fenomenologica delle radici metafisiche dello sport in prospettiva teologica ed educativa [Being as movement: A hermeneutical 
phenomenological analysis of the metaphysical roots of sport in light of a theological and educational perspective]. In D.G. Murray \& Y. Melo Pereira (Eds.), Metaphysics 2012 (pp. 171-186). Madrid: Fundación Fernando Rielo-UTPL. ISBN: 978-84-86942-96-0

- Isidori, E., López Frías, F.J., \& Ramos Echazarreta, R. (2015). Teaching sport philosophy online: A case study in Italy. Procedia. Social and Behavioral Sciences, 186, 932-938. ISSN: 1877-0428, DOI: http://dx.doi.org/10.1016/j.sbspro.2015.04.025

- Isidori, E. (2014). Etica e Sport di Montagna: la prospettiva filosofico-educativa [Ethics and mountain sports: The philosophical educational perspective]. International Journal of Sports Law and Ethics, 2, 3-15. ISSN: 2408-4166

- Isidori, E. (2014). Derrida's concept about doping and its implications for sport education. In E. Isidori, J. Lopez Frias, \& A. Müller (Eds.), Philosophy, Sport and Education. International Perspectives (pp. 103-117). Viterbo: Sette Città. ISBN: 978887853346-2

- Isidori, E., Maulini, C., \& Javier López Frías, F. (2013). Sport and ethics of weak thought: A new manifesto for sport education. Physical Culture and Sport. Studies and Research, 60, 22-29. ISSN: 2081-2221, DOI: 10.2478/pcssr-2013-0023

- Isidori, E. \& Ramos Echazarreta, R. (2013). Sport and philosophy of hospitality: Three questions on how to rethink contemporary sport education in light of gift and peace. Physical Culture and Sport. Studies and Research, 59, 5-10. ISSN: 2081-2221, DOI: 10.2478/pcssr-2013-0017

- Isidori, E. (2013). Essere, movimento, educazione: per una analisi ermeneutico-fenomenologica dello sport [Being, movement, and education: Contribution to a hermeneutical and phenomenological analysis of sport]. In Quaderni del Laboratorio di Pedagogia generale, Vol. 8 (pp. 3-31). Roma: QUAPEG. ISBN: 9786050356243

- Isidori, E. (2013). El entrenador como educador: la perspectiva de la filosofía de la educación [The coach as educator: The perspective of the philosophy of education]. Revista Internacional de Deportes Colectivos, 15, 68-84. ISSN: 1989-841X

- Isidori, E. (2013). Lo sport come filosofia educativa e sociale: una prospettiva decostruzionista [Sport as an educational philosophy: A deconstructionist perspective].M@GM@, 11. ISSN: 1721-9809

- Isidori, E. (2013). Sport, educazione e valori: una mappa concettuale critica [Sport, education, and values: A concept critical map]. Pedagogika.it, 17, 15-20. ISSN: 1593-2559

- Isidori, E. (2011). Metafisica e sport. Per un fondamento ontologico ed epistemologico della pedagogia sportiva [Metaphysics and sport: Towards an ontological foundation of sports pedagogy]. In Metaphysics 2009 (pp. 93-105). Madrid: Dykinson. ISBN: 9788499822266.

- Isidori, E. (2011). Philosophical paradigms and pedagogical orientations of Italian youth football coaches: A pilot study. In Society, Integration, Education, Vol. 1 (pp. 611-619). Rezekne: Rēzeknes Augstskola. ISBN: 9789984440644

Studies in the methodology of educational research applied to sport

In this area, the contribution of Isidori as first, second, or third author, while he was always responsible for the research carried out, has focused on crucial issues for contemporary sport education. These issues include the following: sport education in the school, the sports coach as educator, and new learning models in sport education. What Isidori has done and is doing consists of developing studies in which theory and practice are strictly tied and coupled so as to allow for the development of a sport science capable of finding a perfect balance between the component of theory and that of practice.

- Maulini, C., Migliorati, M., Isidori, E., \& Miatto, E. (2016). Educazione motoria nella scuola primaria italiana: un'indagine in una scuola del Veneto [Physical education in the Italian primary school: A survey in a school in Veneto]. Formazione \& Insegnamento, 14(2), 251-262. ISSN: 1973-4778, DOI: 107346/-fei-XIV-02-16_19

- Ramos, R., Maulini, C., Migliorati, M., \& Isidori, E. (2016). Adolescents and lifestyles. A study on students' leisure in the province of Rome [Adolescencia y estilo de vida. Estudio del ocio de los escolares de la provincia de Roma]. Pedagogia Social. Revista Interuniversitaria, 28, 127-139. ISSN: 1139-1723, DOI: 10.7179/PSRI_2016.28.10

- Kaya, S., Isidori, E., \& Sarol, H. (2015). An examination of adolescents' attitudes towards leisure activities. International Journal of Human Sciences, 12(2), 485-501. ISSN: 1303-5134, DOI: 10.14687/ijhs.v12i2.3356 
- Isidori, E. (2015). La metafora nell'apprendimento esperienziale. Origini e sviluppi per la formazione [Metaphors and experiential learning: Genesis and development for the human education]. In E. Isidori \& C. Buscarini (Eds.), Metaphoric learning e sport [Metaphoric learning and sport] (pp. 7-23). Roma: QUAPEG. ISBN: 9786050407549

- Isidori, E., Migliorati, M., Ramos Echazarreta, R., \& Maulini, C. (2015). Il questionario per la rilevazione dei profili pedagogici degli allenatori: per un contributo alla ricerca in pedagogia dello sport [The questionnaire to detect the pedagogical profiles of sports coaches: A contribution to the research in sports pedagogy]. Giornale Italiano Della Ricerca Educativa, 14(1), 141-155. ISSN (print): 20389736, ISSN (online): 2038-9744

- Isidori, E., López Frías, F.J., \& Ramos Echazarreta, R. (2015). Agón or Certamen? A philosophical analysis of the Greek-Roman agonistic paidéia and its influence on the conception of contemporary sports. International Journal of Social Science and Humanities Research, 3(3), 101-105. ISSN (print): 2348-3156, ISSN (online): 2348-3164

- Isidori, E., Laterza, E., Maulini, C., \& Migliorati, M. (2015). The training period of sport sciences students: The experience of the University of Rome "Foro Italico." Cqia Rivista, Formazione, Lavoro, Persona, 5(15), 171-181. ISSN: 2039-4039

- Isidori, E., Migliorati, M., Maulini, C., \& Ramos Echazarreta, R. (2015). Educational paradigms and philosophy of football coaching: A theoretical and practical perspective. Procedia. Social and Behavioral Sciences, 197, 614-621. ISSN: 1877-0428, DOI: 10.1016/j.sbspro.2015.07.203

- Sandor, I., Ganea, I.V., Isidori, E., Pascan, A., \& Rusu, G.V. (2015). Study of body values in the context of new master programs. A comparative analysis among students from three master programs of physical education and sport faculty in Cluj-Napoca. Studia Universitatis Babes-Bolyai. Educatio Artis Gymnasticae, 60(1), 5-12. ISSN: 1453-4223

- Migliorati, M., Ramos Echzarreta, R., Maulini, M., \& Isidori, E. (2014). Gli stereotipi etnico-sportivi negli studenti italiani: un'indagine nelle scuole secondarie della provincia di Roma [The ethnic stereotypes tied to sport in Italian students: The results from a survey in some secondary schools in the province of Rome]. Giornale Italiano Della Ricerca Educativa, 12, 85-98. ISSN (print): 2038-9736, ISSN (online): 2038-9744

- Migliorati, M., Ramos Echazarreta, R., \& Isidori, E. (2014). El ocio físico-deportivo de los adolescentes tanzanos. Un acercamiento a la realidad social [Leisure and sport in adolescents from Tanzania: An interpretation of their social world]. Revista Internacional de Deportes Colectivos, 17, 61-76. ISSN: 1989-841X

- Isidori, E. et al. (2010). Analyzing body values in the context of postmodern youth education. A comparative study among Italy, Latvia and Romania. Physical Culture and Sport. Studies and Research, 49, 65-71. ISSN: 2081-2221, DOI: 10.2478/v10141-010-0017-X

- Isidori, E., Vossel, T., \& Maulini, C. (2010). Developing educational values through sport and physical activity: A case study within school education in Italy. Studia Universitatis Babes-Bolyai. Educatio Artis Gymnasticae, 55, 53-63. ISSN: 1453-4223

- Isidori, E., Abele, A., Taddei, F., \& Maulini, C. (2010). Value priorities in the views of Latvian and Italian sport science students. Lase Journal of Sport Science, 1, 81-86. ISSN: 1691-7669

- Isidori, E., Fraile, A., \& Graça, A. (2009). A research on socio-moral dilemmas in school sport in Italy, Spain, Portugal and France. In E. Isidori (Ed.), Outline of Sport Pedagogy: Introduction and Research Essays (pp. 83-103). Roma: Aracne Editrice. ISBN: 978-88-548-2686-1

- Isidori, E. (2007). Il metodo di ricerca biografico in pedagogia dello sport [The biographical research method in sport pedagogy]. In E. Isidori (Ed.), Quaderni del Laboratorio di Pedagogia Generale (Qua.Pe.G), Vol. 2 (pp. 3-18). Roma: Università di Roma "Foro Italico." ISBN: 9788869092503

- Isidori, E. (2004). La ricerca-azione. Note per la formazione degli insegnanti [Action-Research: Notes for teachers' education], pp. 3-20. QUAPEG, Annuario, Roma: Istituto Universitario di Scienze Motorie. ISBN: 9786050359473 
Studies in the education of physical education teachers

The topic of teachers' education has been developed by Isidori in the search for new learning and teaching models for teachers of physical education. These studies have stressed the importance for contemporary physical education teachers to explore new topics and fields of knowledge, including the following: Olympic education, CLIL (Content and Language Integrated Learning) methodology applied to the teaching of PE in school, tools for developing self-reflection and a critical approach to the subject in school, etc.

- Isidori, E., Abele, A., Taddei, F., \& Buzi, E. (2016). The questionnaire to detect the physical education teacher's philosophical profile: From theory to practice. Rivista Italiana di Pedagogia dello Sport, 1(1), 4-18. ISSN: 2499-541X

- Isidori, E., Abele, A., \& Taddei, F. (2016). The philosophy of sports education and its significance for physical education teachers. In L. Daniela \& L. Rutka (Eds.), Challenges and Solutions for Education in the 21st Century. Selected Papers of ATEE 2015 (p. 41-49). Newcastle: Cambridge Scholars Publishing. ISBN: 978-1-4438-1100-2

- Fazio, A., Isidori, E., \& Chiva-Bartoll, O. (2015). Teaching physical education in English using CLIL Methodology: A critical perspective. Procedia. Social and Behavioral Sciences, 186, 918-926. ISSN: 1877-0428, DOI: http://dx.doi.org/10.1016/j.sbspro.2015.04.041

- Chiva-Bartoll, O., Isidori, E., \& Fazio, A. (2015). Educación Física bilingüe y pedagogía crítica: una aplicación basada en el Judo [Bilingual physical education and critical pedagogy: An application based on Judo]. Retos 28(2), 110-115. ISSN (print): 1579-1726, ISSN (online): 1988-2041

- Hadjistefanou Papaellina, C., López Frías, F.J., \& Isidori, E. (2014). Teaching ethics through ancient Olympic myths: A philosophical and pedagogical challenge. Studies in Sport Humanities, 1(15), 18-25. ISSN: 2300-6412

- Isidori, E. \& López Frías, F.J. (2014). Sport, science, and complexity: A pedagogical and methodological reflection. Studia Universitatis Babes-Bolyai. Educatio Artis Gymnasticae, 3, 5-14. ISSN: $1453-4223$

- López Frías, F.J. \& Isidori, E. (2014). Sport and democracy: Philosophical trends and educational challenges in contemporary society. CCD. Ciencia, Cultura, Deporte, 27(9), 189-197. ISSN (print): 1696-5043, e-ISSN: 1989-7413.

- Isidori, E. (2014). Il doping nello sport tra diritto, etica ed educazione [Doping and sport between ethics and education]. Revista Internacional de Derecho y Etica del Deporte, 1, 52-62. ISSN: 2408-4166

- Isidori, E., Maulini, C., \& Echazarreta Ramos, R. (2012). La coopeticion y el deporte “debil”. Una clave para repensar el deporte a la luz de la filosofia de la no violencia [Coopetition and weak sport: A key to rethinking sport in light of a non-violence philosophy]. Revista Portuguesa de Ciências do Desporto, 12, 110-113. ISSN: 1645-0523

- Isidori, E. (2010). Deconstructing sport: When philosophy and education meet in Derrida's thought. Physical Culture and Sport. Studies and Research, 48, 15-20. ISSN: 2081-2221, DOI: 10.2478/v10141010-0002-4

Studies concerning the dual career of student athletes

Finally, the last research area that sees Isidori as a leader of groups and holding the responsibility for national and international projects concerns a crucial topic both for contemporary sport pedagogy and the European Union: the dual career of student athletes. In this area, Isidori has focused his attention on the impact of new Web. 2.0 technologies on the tutoring system of these athletes, the search for new learning and teaching models, and the building of qualitative and quantitative research tools aiming to collect data and information from case studies concerning the dual career of athletes in high school or university.

- Isidori, E., Sánchez Pato, A., \& Decelis, A. (2017). E-tutorship and dual-career of student-athletes: A pedagogical conceptualization from the results of an Italian case study. In L. Gómez Chova, A. López 
Martínez, \& I. Candel Torres (Eds.), Proceedings of the 11th Annual International Technology, Education and Development Conference, INTED, 2017 (p. 8028-8037). Valencia: International Association of Technology, Education and Development (IATED). ISBN: 9788461784912, DOI: 10.21125/inted.2017.1893

- Isidori, E. (2016). The dual career of student athletes and the quest for a personalized tutorship model. International Journal of Novel Research in Education and Learning, 3, 9-15. ISSN: 2394-9686

- Migliorati, M., Maulini, C., \& Isidori, E. (2016). La dual-career degli studenti-atleti nella scuola secondaria: fra teoresi pedagogica e progettualità [The dual career of student-athletes in secondary school: Between pedagogical theory and projects]. Formazione \& Insegnamento, 14, Suppl., 157-167. ISSN: 2279-7505

- Sánchez-Pato, A., Calderón, A., Arias-Estero, J.L., García-Roca, J.A., Bada, J., Lourdes Meroño, L., Isidori, E., Brunton, J., Decelis, A., Koustelios, A., Mallia, O., Fazio, A., Radcliffe, J., \& Sedgwick, M. (2016). Diseño y validación del cuestionario de percepción de los estudiantes universitarios-deportistas de alto nivel sobre la carrera dual (ESTPORT) [Design and validation of a questionnaire about the perceptions of dual career student-athletes (ESTPORT)]. Cultura, Ciencia y Deporte, 11, 127-147. ISSN: 1696-5043, DOI: $10.12800 / \mathrm{ccd}$

\author{
AUTHOR'S ADDRESS: $\quad$ Emanuele Isidori \\ University of Rome Foro Italico \\ Department of Movement, Humanities and Health Sciences \\ Piazza L. De Bosis, 15, 00194 Roma \\ Italy \\ E-mail: labopedagogia@gmail.com
}

Received: 26 April 2017; Accepted: 12 June 2017 